\title{
Educational robotics in Primary Education. A case in Greece
}

\author{
Robótica educacional no Ensino Fundamental. Um caso na Grécia \\ Robótica educativa en Educación Primaria. Un caso en Grecia
}

Received: 05/21/2021 | Reviewed: 05/29/2021 | Accept: 07/13/2021 | Published: 07/19/2021

\author{
Eirini Chaidi \\ ORCID: https://orcid.org/0000-0001-8798-3182 \\ N.C.S.R. "Demokritos", Greece \\ E-mail irhaidi@gmail.com \\ Chrysovalantis Kefalis \\ ORCID: https://orcid.org/0000-0001-8549-4713 \\ N.C.S.R. "Demokritos", Greece \\ E-mail: vkefalis@iit.demokritos.gr \\ Yannis Papagerasimou \\ ORCID: https://orcid.org/0000-0002-7996-7243 \\ N.C.S.R. "Demokritos", Greece \\ E-mail: ypapa@iit.demokritos.gr \\ Athanasios Drigas \\ ORCID https://orcid.org/0000-0001-5637-9601 \\ N.C.S.R. "Demokritos", Greece \\ E-mail: dr@iit.demokritos.gr
}

\begin{abstract}
In recent years, educational robotics is gaining ground in the educational policy of more and more places around the world in both formal and non-formal education programs. Also, the usefulness of educational robotics in special education for the treatment of deficits of students with Learning Disabilities, Attention Deficit Hyperactivity Disorder and Autism, especially at the level of student inclusion, is strongly supported. In the present work, the findings of a pilot educational research in a general education school are presented with the participation of students with special educational needs.
\end{abstract}

Keywords: Educational robotics; Special education; Inclusion; S.T.E.M.

\section{Resumo}

Nos últimos anos, a robótica educacional está ganhando espaço na política educacional de cada vez mais lugares ao redor do mundo em programas de educação formal e não formal. Além disso, a utilidade da robótica educacional em educação especial para o tratamento de déficits de alunos com Dificuldades de Aprendizagem, Transtorno de Déficit de Atenção e Hiperatividade e Autismo, especialmente no nível de inclusão do aluno, é fortemente apoiada. No presente trabalho, os resultados de uma pesquisa educacional piloto em uma escola de educação geral são apresentados com a participação de alunos com necessidades educacionais especiais.

Palavras-chave: Robótica educacional; Educação especial; Inclusão; S.T.E.M.

\section{Resumen}

En los últimos años, la robótica educativa está ganando terreno en la política educativa de cada vez más lugares del mundo en programas de educación tanto formal como no formal. Además, se apoya firmemente la utilidad de la robótica educativa en educación especial para el tratamiento de déficits de estudiantes con discapacidades de aprendizaje, trastorno por déficit de atención con hiperactividad y autismo, especialmente a nivel de inclusión estudiantil. En el presente trabajo se presentan los hallazgos de una investigación educativa piloto en una escuela de educación general con la participación de estudiantes con necesidades educativas especiales.

Palabras clave: Robótica educativa; Educación especial; Inclusión; S.T.E.M.

\section{Introduction}

Technologies are an integral part of the education of both formal development students and students with special educational needs. It is also well known that in recent years many countries around the world have incorporated in their educational policy, educational robotics (EP) also known as STEM education in both formal and non-formal education programs, through which students explore various subjects with the use of computers, electromechanical components and 
software. STEM includes the courses: Science, Technology-Engineering, Engineering, and Mathematics, while there is also STEAM which includes Art meaning the humanities, dance, theater etc.

New technologies or Emerging technologies are technologies that are considered capable of changing the state of things, are characterized by innovations, rapid growth, continuity, obvious impact on the socio-economic level of the future, but also uncertainty and ambiguity at present. "(Rotolo et al., 2015)

New technologies are educational technologies, information technologies, nanotechnology, biotechnology, cognitive sciences, psychotechnology, robotics, and artificial intelligence. (el.wikipedia.org, 2021)

Robotics is the branch of technology that deals with the design, construction, operation, and applications of robots, (Psara, 2016) and computer systems for performing controls, feedback, and information processing, automated machines that can replace a human in dangerous environments or production processes, or look like people in appearance, behavior, and/or knowledge.

Educational robotics is a relatively new scientific discipline that deals with the construction, programming, and utilization of robots at various educational levels. As a subject, it is part of the computer science course and aims to plan activities to enhance computational thinking skills. In recent years, educational robotics has become very popular in both primary and secondary education, due to the effective help it offers to students to acquire problem-solving skills.

Regarding educational robotics as a tool to approach knowledge in special education, for children with learning disabilities, dyslexia, autism, attention deficit hyperactivity disorder (ADHD) it is argued that it is a "tool" useful to eliminate students' disabilities and deficits as well, helps students acquire skills, develop self-esteem and access knowledge.

Robots have the ability to provide an alternative learning method for students, using the multiple arrays of sensors available in modern robots, so that they can be programmed to interact with students in specific ways, to encourage and engage them in learning activities thus motivating him to be actively involved in the learning process.

The CODESKILLS4ROBOTICS project is an Erasmus+ project in which organizations from Greece, Cyprus, Belgium and Sweden participate. The project aims to introduce 'coding and robotics' to primary school students (9-12) with emphasis to target students with fewer opportunities for participation in innovative programs for the acquisition of digital skills such as students with learning disabilities.

\section{Methodology}

In this article on "Educational robotics in primary education. A case in Greece ". We have made an effort to explore the impact that the implementation of a robotics curriculum will have on a school that supports integration.

Through the implementation of the program, with a mixed teaching model: live and distance, in a general school with students of formal development but also students with special educational needs (autism, ADHD, learning disabilities), the results, positive or negative, were studied. reactions, the effects of educational robotics both in the typical school population, but especially in students with parallel support and special needs.

By observing and recording the needs and deficits of students, with direct and indirect observation from the beginning of the implementation of the program and any of their behaviors and reactions during the program, as well as the "influence" of robotics on students, the research led to the conclusions that will be reported below.

\section{Technologies and Education}

In recent years, 3 factors have been involved in education that promote Children's learning and Communication with the help of Computers. 
Information and Communication Technologies are now an integral tool of the educational process for modern educational systems, influencing the structure and operation of educational institutions by providing education to students with more interactive methods and educational pedagogy.

Technology helps the learning process change from passive to active because it can make each student more independent and autonomous, turning skills into skills and giving students the guarantees to become autonomous critical thinking individuals.

\section{Educational Robotics}

Education is "coordinated" in the era of social and technological changes is redefined in the context of the requirements of the "knowledge society", computer literacy focuses on pedagogical issues, with the help of digital media: a) enriching the educational process in multiple sources hardware and communication tools, b) improving the quality of the teaching and learning process.

Today there are 4Rs and they play an important role in the learning process. THE 4R OF LEARNING are; Reading, wRiting, aRithimetic, Robotics.

Robotics is a branch of engineering that deals with the design and construction of robots derived from the word robota, which means "work" and is applied in many areas of human activity, including medicine, industry and education. recent years. (www.maxmag.gr, 2021)

The history of educational robotics dates back to the late 1950s and 1960s when scientists-programmers began thinking about creating software to develop students' mathematical thinking. The result was the creation of the LOGO language (Seymour Papert, Wally Feurzeig, and Cynthia Solomon, 1980) and then the invention of the first "turtle " training robot. (Dimitriadis, 2015)

Papert, a supporter of Piaget's ideas on the theory of constructivism, takes the view that the learning approach is more effective when there is active involvement of students in the learning process, when they construct specific objects that interest them, they collaborate with each other and develop social behavior as they interact (Blanchard et al., 2010).

Educational Robotics is based on the theories of Piaget's constructivism, Papert's constructionism, and Vygotsky's socio-cultural vision, with the goal of developing superior mental skills related to building new knowledge through discovery, problem solving, and collaboration ( Gura, 2007, Hussain et al., 2006).

Educational Robotics introduces another way of the knowledge building approach, more fun through the game " learning through play, (LEGO Dacta A / S, 1999; Jarvien et al., 2000; Gura, 2007) and enables, motivation for students to engage, to construct objects that have interest/meaning (Resnick et al., 2005) for them as a result of which scientists "feel" and try to approach the concepts of the cognitive object directly, confirming (Alimisis, 2009) one of the basic principles of robotic graded difficulty: " low floor, high ceiling and wide walls "(" low floor, high ceiling and wide walls ") starting from very easy (low floor) and continuing to create complex and sophisticated programs and constructions (high ceiling) and finally exploring robotics to too many directions, scientific fields or interests (wide walls) with imagination and without limits.

As already mentioned, educational robotics seems to be a useful tool in the educational process of learning and to attract the interest of students. However, researchers argue that although robotics presents many positive elements that support the development of learning skills, more research is needed on the pedagogical context of teaching (Mataric, 2004; Alimisis, 2013) as it is argued that the change in the thinking of To achieve higher learning achievements/results (Papert, 1991), robotics activities need to be based on appropriate educational environments to aim through the pedagogically documented 
methodology and pedagogical material to enhance their educational teaching with the utmost knowledge by students ( Eteokleous-Grigoriou et al., 2013; Benitti, 2012).

It is generally accepted that for the successful integration of educational robots in the educational levels, two key factors are needed: a) the existence of robots as constructions and learning tools in school and b) the creation and appropriate pedagogical utilization of electronic infrastructures that provide the ability to support learning platforms for learning, programming, and user/student interaction and training robots (Petre et al., 2004).

\section{Educational Robotics and Typical Education}

In recent years, research has been conducted on the use of robotics education which shows that EP can be used effectively in various educational fields, enabling students to develop cognitive, metacognitive, and social skills (Atmatzidou et al., 2012).

Several studies suggest that EP is a new enjoyable/playful way of approaching learning, which allows the student to "motivate" them to participate, to be actively involved in the learning process, and to promote cooperation, confidence, selfaction, students 'creativity, and socialization, while "helping" the development and improvement of students' critical thinking, problem-solving and metacognitive skills (Alimisis, 2013; Gura, 2007; Atmatzidou, 2018).

Researchers claim that there are positive results of educational robotics (La Paglia et al., 2010) in improving the skills of both students' cognitive and metacognitive skills and problem solving skills (Lin et al., 2011; Gaudiello et al., 2013; Huang et al., 2014; La Paglia et al., 2011), while others report significant positive effects on learning (Keren et al., 2014; Gama, 2004a). Although the research results are positive, the researchers argue that a more detailed analysis is needed (Huang et al., 2014), as well as a larger number of samples as most studies have a small sample, (Lin et al., 2011; Gama, 2004a). One aspect that researchers have pointed out is that some studies have applied strong guidance to the development of students' metacognitive and problem-solving skills (Gama, 2004b; Kramarski et al., 1997; Ishii et al., 2006a; Ishii et al., 2006b; Lai, 1990; La Paglia et al., 2011), while others report a rather minimal guidance (Lai,1993; Lo Ting-kau., 1992; McWhorter, 2008; Nourbakhsh et al., 2005; Gama, 2004a).

Other researchers argue that engaging in educational robotics helps to learn a programming language ( Atmatzidou et al., 2008; Vollstedt et al, 2007; Mataric, 2004) by increasing students' interest and involvement in science, technology, engineering, and mathematics (STEM), pushing them to pursue a career in one of these areas (Mataric et al.,2007; Mead et al., 2012; Eguchi, 2014; Kubilinskiene et al., 2017; Stoumpou et al.,2013).

Robots are programmable objects and therefore particularly useful for teaching programming as researchers claim (Lawhead et al., 2003). The use of robots (Lego Mindstorms) has advantages (Karatrantou et al., 2005) teaching objectoriented programming languages and in understanding the basic principles, concepts and structures of programming, (Vounatsos et al., 2011). In other research developed as part of the TERECoP Project (www.terecop.eu), a catapult was designed and built using Lego Mindstorms (Charos et al., 2009), and "Easy Parking" through an educational activity(Barnes, 2002), reinforcing the view that educational robotics "helps" in the teaching of structured programming with the use of robots.

Other researchers have also studied activities such as the use of computer-controlled models for teaching Java (Xynogalos, 2009), teaching programming to high school students using Karel microcosm programming (Moro et al., 2009) and educational activities where students program a robotic vehicle to behave like a typical Logo turtle, "listen" to the basic Logo commands (Turner et al., 2007).

Although the usefulness of educational robotics is supported, there is research to support the view that its activities do not yield the expected significant benefits (Williams et al., 2007; Nourbakhsh et al., 2005; Huang et al., 2014) nor the expected 
development and improvement of skills. of students involved in the knowledge approach to learning (Jarvinen et al., 2000; Sullivan et al., 2013; Raffle et al., 2004; Petre et al., 2004).

\section{Robotic and Special Education}

The idea for the use and application of robotics in children with educational needs appeared in the 1970s by Seymour Papert, the inventor of the Logo language, a proponent of constructivism in education, and an opponent of disability theories of the time that focused on what the child could not do.

The invention of the LOGO and the robot turtle was inspired by a completely opposite belief as Papert's goal and he worked for it was to enable as many people excluded from society as possible to take an active part in many activities.

The use of robotics in the field of special education for the education of people with special educational needs obviously can enhance the ability and ability of a child to turn them into skills to approach the learning process and therefore knowledge always guided its peculiarities and shortcomings, as reflected in the PISA reports of the international organization OECD (Armstrong, 2004).

Educational robotics also contributes to the process of inclusive education/inclusion of people with disabilities. Inclusive education/inclusion of the student with special needs is one of the factors that shape the educational process and the structure of the school in general as inclusive education includes concepts of equality, anti-racism and intercultural education, a social perspective, and a human rights perspective. justice and equality of individuals (Christoforaki, 2008).

It is self-evident for a successful inclusion/integration education, with the help of educational robotics the basic condition is the existence of appropriate material and technical equipment for the needs of all children (Hammill, 1990).

Educational robotics and its entry into education in recent years have greatly improved the performance of children with learning disabilities, dyslexia, ADHD, and autism. Children with the use of appropriate educational material can enhance their self-confidence, cultivate skills, enhance empathy, feel that they offer to the team, improve their socialization, as well as cultivate communication and verbal expression of ideas through group function when students are forced to explain their ideas and thoughts. Also, educational robotics combines learning the game and thus turns education into a fun activity, actively involves students in learning while respecting their particularities and abilities, allows free expression and the development of creativity and imagination, provides immediate feedback, supports experiential learning by motivating them to engage students with something interesting.

\subsection{Autism and Educational Robotics}

The goal of robotics concerning children with autism is to cultivate skills e s sectors presenting to Brussels I made to share their interest with typical development children, socialize more easily with their peers (interaction), to share experiences, and collaborate (socialization)

Also, children with autism have a deficit in understanding facial expressions, robots without expressions, do not distract children and thus devote themselves to completing the activity.

Robotics using: LEGOwedo and LEGO Mindstorms can encourage students with autism to master: the skill of collaboration through storytelling and consequently, the cultivation of language skills, to cultivate teamwork through interactive activities, and enhancing empathy.

Today in the application of applications with self in friendly and emotional requirements, the robots Diagnostic appearances with children with authentic distinctions in interactions with each time required in friendly characters in prayer and expression of emotions. Many students are analyzed in the use and deficits that require "robots": "Mechanics", with the 
tools they need, every time I need to do, do, do, do, do any interaction, do different users, with different content, different users. .

Regarding creations 3 intermediate information that we "have" in the equipment with the configurations of the spectrum of the original (ASD).

Figure 1: Robots for autismo.

\begin{tabular}{|c|c|}
\hline & $\begin{array}{l}\text { 1) A humanoid robot helps children with Aut ism Spectrum Disorder! } \\
\text { NSF Science Now } 12 \\
\text { https://www.youtube.com/watch?v=ecdgKVE4Zis\&feature=share... }\end{array}$ \\
\hline & $\begin{array}{l}\text { 2) A "robot" teachessocial skills to children with aut ism !!! } \\
\text { https://spectrum.ieee.org/the-human-os/biomedical/devices/robot- } \\
\text { therapy-for } \\
\text { autism?fbclid=IwAR1oWFKvf8QicohDnc9do_dcqskzApKJuZC52 lhjg3- } \\
\text { FQ6k-QsquHUcgrys }\end{array}$ \\
\hline & $\begin{array}{l}\text { 3. Learning social skills with Milo !! } \\
\text { https://www.robot icsbusinessreview.com/health-medical/social- } \\
\text { skills-milo-robot-helps-children-autism/?fbclid=IwAR3UhAZ- } \\
\text { MIGAaqntL2v5tIkIEQ315-M4HOGqokTLFmraX-IG9tSOwWF j4 }\end{array}$ \\
\hline
\end{tabular}

Source: Authors.

1. An interdisciplinary approach to mechanical engineering and special technical data required robotic system and dismantling to dispose of the tarot robots we need to make for each application for the various key elements of the personal information content on the substance. Research blueprints with a technically sophisticated system of cameras, preserves and photographs required designed to use children in learning color images.The protagonists are Aiden a year and a half with various disturbances in his range and NOA a humanoid robot that "every" commands and application for the selection of standard exercises. From the use of the robot to students with ASD the educators looking for the children gave access to the robot and learned its application. : (https://news.vumc.org/, 2021)

2. QTrobot is separated from LuxAI to let children learn to interact with the different, with the required messages that require different, emotional and cognitive questions. QTrobot separates with children's, laughs softly, speaks softly, questions, availability and mood, availability of details, availability of users, we use the information in children with special differences. "Access interacts with a separate, segregation whenever required by details, tone of voice and application of the issue that are overwhelming and snippets for children with eggs, the overnight telephony robots. For example, whenever the robot disputes or runs, I need time with the required and required person each time with it. "Aida Nazarikhorram, co-founder of LuxAI.( www.fnr.lu, 2021)

3. Released in 2013 by RoboKind, Milo where lessons were reshaped with a voice targeting different people, emotions, illustrations, additional photos and personal information. Pupils teach Milo's prospective prompts and intermediate information to questions that require contacts, emotions and expressions of empathy with the questions in Milo's game: angry, sad, happy, frustrated - types of photography that should I am doing. like students layered by televisions from near to far, does not dance for the right quests.(https://www.edutopia.org , 2021) 


\subsection{ADHD and Educational Robotics}

The disorder deficit attention and hyperactivity disorder (ADHD) affects the ability of the child to Respondent to Tai in the same position throughout ( hyperactivity ), to stay focused on something for a long time (attention deficit), to control his behavior. He is also very active, hyperactive, and impatient and finds it difficult to follow instructions.

STEM robotics ( Science, Technology, Engineering, and MathematicsSTEM) is experiential and interactive and the activities used to educate students in problem-solving, creating, and programming a robot to aim to keep the children's interest undiminished, to facilitate children in the management of their behavior and their symptoms (hyperactivity-distraction) to use their energy by making constructions, to cultivate the cooperation between the children (socialization) to feel that they offer to the group and to cultivate their skills and of course boost their confidence.

\subsection{Learning Difficulties and Robotics}

"Learning disabilities are defined, in a general term, as a heterogeneous group of disorders which manifest with significant difficulties in acquiring and using listening, speaking, reading, writing, reasoning or mathematical skills.

These disorders are inherent in the individual and are attributed to central nervous system dysfunction and can exist throughout life.[40] They are not learning disabilities the $\mathrm{p}$ handicaps in self-control behaviors, social perception and social interaction that can coexist with learning disabilities, as well, and learning difficulties which occur accompanying with other statements deficit: sensory impairment, mental retardation, serious emotional disturbance) or with external situations: cultural differences, insufficient or inappropriate teaching.

Today there is an effort to develop software -ordination will enable a range of customizable learning tools to collaborate with various types of robots to fit the learning in a personalized training program for the deficits of the student. Research programs aim to show that cognitive development can be enhanced through robot-mediated learning by developing other social skills as well, taking advantage of robotics. (STEM, 2021)

Educational robotics seems to benefit et significantly students with dyslexia as not using the present improvements important as language skills in reading and writing, speaking and the hearing of this, and the acquisition of capacity usefulness of cooperation and socialization through their participation in joint activities with other children.

\section{The CODESKILLS4ROBOTICS}

The CODESKILLS4ROBOTICS project is an Erasmus+ project in which organizations from Greece, Cyprus, Belgium and Sweden participate. The project aims to introduce 'coding and robotics' to primary school students (9-12) with emphasis to target students with fewer opportunities for participation in innovative programs for the acquisition of digital skills such as students with learning disabilities. A field study was conducted in the participating countries from which conclusions were drawn regarding the needs of students and teachers in the fields of new technologies and educational robotics.

Taking into account the results of the field research, educational material for educational robotics was developed, designed appropriately for the needs of students of general population but also for students with educational difficulties.

In essence, the Educational Material contains 3 Modules:

Module 1 (Develop Basic STEM Skills \& Programming) is designed primarily for helping students acquire basic programming and robotics skills using a custom-made robot (named R.E.A.). Module 1 provides simple instructions so that participants are acquainted with the different building bricks $\&$ the more advanced parts of the educational robotics kit (drive base, motors, sensors). Simple constructions such as motors $\&$ sensors are implemented in a step-by-step way before moving to more advanced constructions such as gear setups \& variables. 
In this way students are introduced to the basic programming principles smoothly by coming into contact with basic programming principles (eg loops coding concept) while gradually learning more advanced programming principles. Through these activities' students acquire skills beyond those of programming such as:

Fine motor skills: if the students are involved not just in programming, but also in physically building their robots, then robotics is a subject that keeps up with the latest technology trends while keeping them away from screens and encouraging them to use their hands and learn by doing.

Teamwork: the many phases of building, programming and testing a robot are usually performed by a team, which teaches students to work together for a common goal.

Thinking outside the box: creating a robot from scratch sharpens the students' creativity and problem-solving abilities by giving them a task to perform and showing them that there are several valid ways to do it. Students are in complete control of the process, which keeps them engaged and attentive and makes the project rewarding and fun.

Perseverance: a robot built by a team of students likely will not work correctly on their first try. Assembling and programming a robot is a trial and error process that teaches the patience and humility to retrace your steps and correct your own mistakes, and a healthy dose of stubbornness that drives you to try harder next time.

In Module 2, the focus is on the implementation of four (4) cross-curricular scenarios each based on the subjects of history, space, culture \& environment in an attempt to introduce coding, robotics \& STEM skills in primary schools in an innovative way. In these scenarios the pupils will use three (3) of the main constructions of the educational robotics kit, namely, Vernie, M.T.R.4 and Guitar 4000.

The development of four (4) cross-curricular scenarios is based on the constructivism theory according to which, knowledge is a continuous \& active process. Students must seek knowledge \& solve problems on their own, synthesizing new ideas, structures, models, \& concepts \& linking them to previous knowledge $\&$ mental models. Real experiences are important for the learning process, hence for constructive learning, both the content of the information as well as the context are important. Thus, inquiry-based cross-curricular scenarios were selected to be used as educational material, which are inspired by everyday life, the environment, arts, etc. in order to motivate the participants $\&$ inspire teachers to introduce coding, robotics \& STEM skills in primary schools. The benefits of the cross-curricular approach are:

- links various subjects of the National Curricula \& skills together in a meaningful way

- fascinating topic for children to work on

- holistic approach into dealing with learning

- applies skills \& competences into concrete tasks, e.g., make a robot follow a route, solve problems in math to calculate distance \& time, etc.

Finally, Module 3, which is essentially a guide for teachers to teach more advanced robotics inspired by science and real robotics applications together with indicative worksheets and ideas on how to organize the teaching process.

The fact that diverse organizations had the opportunity to exchange opinions regarding the formation of the educational material has had a significant impact on the people involved \& their organizations, as they will benefit both at the professional level from their use, as well as at practical level as all products will be ready for re-implementation. It is expected that the material will affect teachers, students \& schools \& will fulfil its goal to introduce coding, robotics \& STEM skills in schools enhancing thus the professional profile of teachers \& equipping students with the necessary e-skills in accordance with the needs of the labor market. 
All materials are easily transferable to other sectors \& countries that would like to implement such a training. They are easy to follow \& can be used by other organizations that want to use or upgrade them. They can be further exploited by the partners in their everyday practice.

All the educational material is uploaded on the project e-learning platform (http://codeskills4robotics.i it.demokritos.gr/) and it is freely available to everyones.

\section{The Case of the 11th Primary School of Maroussi}

During the pilot testing phase of the project a lot of schools of all participated countries joined. Among them was the 11th Primary School of Maroussi. The pilot testing took place directly after school hours (extended zone) for 1,5 to 2 hours per day on a 3 to 4 days per week basis. Twelve children took part in the pilot testing phase and formed two groups of six. During the pilot implementation a blended learning approach was followed. Of course, this was the plan from the beginning, but the fact that primary schools closed due to Covid 19 situation, led us to distance learning and the use of the online platform became central to this process. In total, for each group 7,5 hours were held in-class while 32 hours of training took place online.

In the distance learning phase, technical support was provided so that the teaching process became as interactive as possible. The teacher had the appropriate equipment at his disposal so that the students could see in real time the programming process and the subsequent actions of the robot. This procedure was necessary since the process of learning by doing is central to educational robotics and the fact that students did not have a Lego Boost kit at home made this process very difficult. However, the ability of the students to program the robot in real time and immediately see on their screen live what the robot does, made the lesson much more interesting and interactive for the students. It is worth noting that during the distance learning phase the two groups of children were united, since the children no longer had to form smaller groups.

Out of a total of 12 who participated 5 were students with fewer opportunities. Two of the students were students with learning difficulties. One student has been diagnosed with a developmental disorder. One student has been diagnosed with ADHD and one with emotional immaturity.

All students were fully involved in the activities. The children worked in groups that were shaped in such a way that the children who wanted some help received it from both their teacher and their peers. The groups consisted of a child with a special need and a peer of typical development, while the teacher was well aware of the specific cases and would intervene if needed with further explanations and support. If a child needed more time for completing an activity it was given the opportunity to do it at his/her own pace. All students had the opportunity to study the educational material at home at their own pace through the e- platform which was really useful especially for the children with learning difficulties.

\section{Final Considerations}

In the program report it would be of added value to mention the phrase of a student with autism: "How glad I am to have friends".

This phrase confirmed our view that students with or without educational needs enjoyed their participation, were enthusiastic about the programming and operation of the robot, actively participated in the whole educational process, collaborated, created.

Students with special needs, in particular, used their skills and turned them into skills, managed their deficits, socialized and felt accepted, thus boosting their self-esteem. 


\section{Acknowledgements}

The CodeSkills4Robotics project has been co-funded by the Erasmus+ Pogramme of the European Union (Grant Agreement No: 2018-1-EL01-KA201-047823).

\section{References}

Alimisis, D. (2009). Teacher Education on Robotics- E enhanced Constructivist Pedagogical Methods. School of Pedagogical and Technological Education (ASPETE), Athens. http://www.terecop.eu/ en / Products1.html.

Alimisis, D. (2013). Educational robotics: Open questions and new challenges. Themes in Science and Technology Education, 6 (1), $63-71$.

Armstrong, D., (2004). "Integration, participation and democracy". In A. Zoniou - Sideris \& I. Spandagou (eds.), Education and Blindness, Greek Letters, Athens

Atmatzidou, S., Markelis, I., \& Demetriadis, S. (2008). The use of LEGO Mindstorms in elementary and secondary education: game as a way of triggering learning. In Workshop Proceedings of International Conference on Simulation, Modeling, and Programming for Autonomous Robots (pp. 22-30).

Atmatzidou, S., \& Demetriadis, S. (2012). Evaluating Role of Collaboration Scripts as Group Guiding Tools in Activities of Educational Robotics: Conclusions from Three Case Studies. In IEEE 12th International Conference on Advanced Learning Technologies (ICALT), 2012 (pp. 298-302). 10.1109/ ICALT.2012.111

Atmatzidou Soumela (2018) Educational robotics as a means of developing students' computational thinking and metacognition, PhD Thesis Aristotle University of Thessaloniki School of Sciences, Department of Informatics, Thessaloniki, 2018.

Barnes, D. J. (2002). Teaching introductory Java through LEGO MINDSTORMS models. Proceedings of the 33rd SIGCSE technical symposium on Computer science education, ACM.

Benitti, F. B. V (2012). Exploring the educational potential of robotics in schools: A systematic review. Computers \& Education, 58 (3), 978-988. 10.1016/ j.compedu.2011.10.006.

Blanchard, S., Freiman, V., \& Lirrete-Pitre, N. (2010). Strategies used by elementary schoolchildren solving robotics-based complex tasks: the innovative potential of technology. Proceedings of Social and Behavioral Sciences 2 (2010). WCES-2010, 2851-2857. 10.1016/j.sbspro.2010.03.427

Charos, S., \& Trakantzidis, I. (2009). Use of robotics in teaching programming structures: "Easy parking". Proceedings of the 5th Panhellenic Conference of ICT Teachers, Syros.

Christoforaki K., (2008). "Access - The integration of children with disabilities in the school process", at www.prosvasi.uoa.gr

Dimitriadis, S., 2015. Learning theories and educational software. Athens: Association of Greek Academic Libraries. http://hdl.handle.net/11419/3397

Eguchi, A. (2014). Robotics as a learning tool for educational transformation. In Proceeding of 4th International Workshop Teaching Robotics, Teaching with Robotics \& 5th International Conference Robotics in Education Padova (Italy).

Eteokleous-Grigoriou N. \& Psomas C. (2013). Integrating Robotics as an Interdisciplinary Educational Tool in Primary Education. In Society for Information Technology \& Teacher Education International Conference, (1), 3877-3881.

Gama, C. (2004a). Metacognition in interactive learning environments: The reflection assistant model. In Intelligent Tutoring Systems (pp. 668-677). Springer Berlin / Hei-delberg.

Gama, C. (2004b). Integrating Metacognition Instruction in Interactive Learning Environ-ments. PhD Thesis, University of Sussex. Sussex, UK.

Gaudiello, I., \& Zibetti, E. (2013). Using control heuristics as a means to explore the educational potential of robotics kits. Themes in Science and Technology Educa-tion, 6 (1), 15-28.

Gura, M. (2007). Student Robotic Classroom Robotics: Case Stories of 21st Century Instruction for Millennial Students (pp. 11-31). Charlotte: Information Age Publishing.

Hammill, D. D. (1990). On Defining Learning-Disabilities: An Emerging Consensus. Journal of Learning Disabilities, 23, 74-84. http://dx.doi.org/10.1177/002221949002300201

Huang, L., Varnado, T., \& Gillan, D. (2014). Exploring Reflection Journals and Self-efficacy in Robotics Education.In Proceedings of the Human Factors and Ergonom-ics Society Annual Meeting. 58(1), 1939-1943. SAGE Publications.

Hussain, S., Lindh, J., \& Shukur, G. (2006). The effect of LEGO training on pupils' school performance in mathematics, problem-solving ability, and attitude: Swedish data. Educational Technology \& Society, 9 (3), 182-194.

Ishii, N., Suzuki, Y., Fujiyoshi, H., Fujii, T., \& Kozawa, M. (2006a). Designing Learning Environments for Creativity in Engineering Education. Proceedings of the 5th WSEAS International Conference on Education and Educational Technology, Tene-rife, Canary Islands, Spain, December 16-18, (pp. 22-27).

Ishii, N., Suzuki, Y., Fujiyoshi, H., Fujii, T., \& Kozawa, M. (2006b). A framework for designing learning environments fostering creativity. Current developments in tech-nology-assisted education, 228-232. 
Research, Society and Development, v. 10, n. 9, e17110916371, 2021

(CC BY 4.0) | ISSN 2525-3409 | DOI: http://dx.doi.org/10.33448/rsd-v10i9.16371

Jarvinen, E., \& Hiltunen, J. (2000), Automation technology in elementary technology education, Journal of industrial teacher education, 37 (4), $51-76$

Karatrantou, A., Tachos, N., \& Alimisis, D. (2005). Introduction to basic principles and programming structures with the LEGO Mindstorms robotic constructions. Proceedings of the 3rd Panhellenic Conference "Didactics of Informatics", Corinth.

Keren, G., \& Fridin, M. (2014). Kindergarten Social Assistive Robot (KindSAR) for children's geometric thinking and metacognitive development in preschool educa-tion: A pilot study. Computers in Human Behavior, 35, 400-412.

Kramarski, B., \& Mevarech, Z. R. (1997). Cognitive - metacognitive training within a problem - solving based Logo environment. British Journal of Educational Psychology, 67 (4), 425-445.

Kubilinskiene, S., Zilinskiene, I., Dagiene, V., \& Sinkevicius, V. (2017). Applying Robotics in School Education: a Systematic Review. Baltic J. Modern Computing, 1 (5), pp. 50-69.

Lai, K. W. (1990). Problem solving in a Lego-Logo learning environment: cognitive and metacognitive outcomes. Computers in Education, Elsevier, Amsterdam, 403-408.

Lai, K. W. (1993). Lego-Logo as a learning environment. Journal of Computing in Childhood Education 4 (3), 229-245.

La Paglia, F., Rizzo, R., La Barbera, D., \& Cardaci M. (2010). Using robotics construction kits as metacognitive tools: a research in an italian primary school. Annual Review of Cybertherapy and Telemedicine: Advanced Technologies in the Behavioral, Social, and Neurosciences, 154, 110-114.

La Paglia, F., Rizzo, R., \& La Barbera, D. (2011). Use of robotics kits for the enhancement of metacognitive skills of mathematics: A possible approach. Studies in Health Technology and Informatics, 167, 26-30.

Lawhead, B. P., Bland, G. C., Barnes, J. D., Duncan, E. M., Goldweber, M., Hollingsworth, G. R., et al. (2003). A Road Map for Teaching Introductory Programming Using LEGO Mindstorms Robots. ACM SIGCSE Bulletin, (pp. 191-201), Reno, Nevada, USA.

Lin, C. H., \& Liu, E. Z. F. (2011). A pilot study of Taiwan elementary school students learning motivation and strategies in robotics learning. In International Conference on Technologies for E-Learning and Digital Entertainment (pp. 445-449). Springer Berlin Heidelberg.

Lo Ting-kau. (1992). Lego TC logo as a learning environment in problem- solving in advanced supplementary level design \& technology with pupils aged 1619. (Master's thesis). University of Hong Kong, Pokfulam, Hong Kong.

Mataric, M. (2004). Robotics Education for All Ages. In Proceedings, AAAI Spring Symposium on Accessible, Hands-on AI and Robotics Education, Palo Alto, CA, Mar 2224. https://www.aaai.org/Papers/Symposia/Spring/2004/SS-04-01/SS04 -01-004.pdf.

Mataric M., Koenig N., \& Feil-Seifer D., (2007). Materials for Enabling Hands-On Robotics and STEM Education. In AAAI Spring Symposium: Semantic Scientific Knowledge Integration 99-102. http://www.aaai.org/Papers/Symposia/Spring/2007/SS-07-09/SS07-09-022.

McWhorter, W. (2008). The effectiveness of using LEGO Mindstorms robotics activities to influence self-regulated learning in a university introductory computer programming course. (Doctoral dissertation). University of NorthTexas

Mead, R., Thomas, S., \& Weinberg, J. (2012). From Grade School to Grad School: An Integrated STEM Pipeline Model through Robotics, in: Robot K-12 Education: A New Technology for Learning, IGI Global, ch 15 302-325. 10.4018 / 978-1-4666-0182-6.ch015.

Moro, M., \& Alimisis, D. (2009). From the Logo Turtle to the Tiny Robot Turtle: practical and pedagogical issues. Proceedings of the 5th Pan-Hellenic Conference "ICT in Education, Syros (Greece).

Nourbakhsh, I. R., Crowley, K., Bhave, A., Hsium, T., Hammer, E., \& Perez-Bergquist, A. (2005). The robotic autonomy mobile robotics course: Robot design, curriculum design and educational assesment. Autonomous Robots, 18 (1), 103-127. 10.1023 / B: AURO.0000047303.20624.02.

Papert, S. (1991). Situating Constructionism. In S.Papert and I.Harel (eds.) Constructionism, Norwood, NJ, Ablex Publishing Corporation.

Petre, M., \& Price, B. (2004). Using robotics to motivate 'back door' learning. Education and Information Technologies, 9 (2), 147-158.

Psara E. (2016). Educational robotics and development of computational thinking: the effect of students' roles in collaboration. http://ikee.lib.auth.gr/record/282778/files/GRI-2016-16447.

Raffle, H. S., Parkes, A. J., \& Ishii, H., (2004). «Topobo: A constructive assembly system with kinetic memory». In Proceedings of the SGCHI conference on human factors in computing systems, Vienna Austria, pp.

Resnick, M., \& Silverman, B. (2005). Some Reflections on Designing Construction Kits for Kids. In Proceedings of the 2005 conference on Interaction design and children (pp.117-122). ACM. http://lk.media.mit.edu/papers/IDC2005.pdf

Rotolo, D., Hicks, D., \& Martin, B. R (2015) What is an emerging technology? Research Policy 44 (10): 1827-1843.

Stoumpou, A., Detsikas, N., \& Alimisis, D., (2013) Teaching the structures of selection and repetition with the tool educational robotics: a case study. Proceedings: 3rd Panhellenic Conference "Integration of ICT in the Educational Process" (2013)

Sullivan A., \& Bers M. U., Gender differences in kindergarteners 'robotics and programming achievement, International Journal Technology and Design Education, 23 (2013) 691-702. 10.1007 / s10798-012-9210-z.

Turner, S., \& Hill, G. (2007). Robots in problem-solving and programming. In 8th Annual Conference of the Subject Center for Information and Computer Sciences (pp. 82-85). 
Research, Society and Development, v. 10, n. 9, e17110916371, 2021

(CC BY 4.0) | ISSN 2525-3409 | DOI: http://dx.doi.org/10.33448/rsd-v10i9.16371

Vollstedt A., M. Robinson, E. \& Wang, (2007). Using Robotics to Enhance Science, Technology, Engineering, and Mathematics Curricula, In Proceedings of the American Society for Engineering Education Pacific Southwest Annual Conference,

Vounatsos, G., \& Mega, A. (2011). The TERECoP methodology and LEGO Mindstorms in secondary education: a case study. Proceedings of the 6th Panhellenic Conference of ICT Teachers, Syros.

Williams, D. C., Ma, Y., Prejean, L., \& Ford, M. J. (2007). Acquisition of physics content knowledge and scientific inquiry skills in a robotics summer camp. Journal of Research on Technology in Education, 40 (2), 201-216.

Xynogalos, S. (2009). Suggestion for Teaching Programming in High School Using the Karel Robot. Proceedings of the 5th Panhellenic Conference of ICT Teachers, Syros.

O'Reilly (2008). Emerging Technology Conference 2008. https://el.wikipedia.org/wiki/\%CE\%9D\%CE\%AD\%CE\%B5\%CF\%82 \% CF\% 84\%CE\%B5\%CF\%87\% CE\%BD\% CE\%BF\% CE\%BB\% CE\%BF\% CE\%B3\%CE\%AF\%CE\%B5\%CF\%82 [2\} other examples of developments described as "emerging technologies" can be found here Archived 2011-06-05 at Wayback Machine. - .

Robotics. (2021). https://el.wikipedia.org/wiki/\%CE\%9D\%CE\%AD\%CE\%B5\%CF\%82 \%CF\%84\%CE\%B5\%CF\%87\%CE\%BD\%CE\%B F\%CE\% BB\%CE\%B F\%CE\%B3\%CE\%AF\%CE\%B5\%CF\%82 [28] «robotics». Oxford Dictionaries.

Maxmag. https://www.maxmag.gr/eidiki-agogi/ekpaideytiki-rompotiki-stin-eidiki-agogi/

Stem-arts. https://www.stem-arts.gr/el/blog/238-ekpaideftiki-rompotiki-kai-eidiki-agogi

robot-helps-children-with-autism.(2013). https://news.vumc.org/2013/03/23/robot-helps-children-with-autism/

autism-robot-helps-children (2013). https://news.vumc.org/2013/04/16/autism-robot-helps-children/

Lab to startup-luxai. https://www.fnr.lu/research-with-impact-fnr-highlight/from-lab-to-startup-luxai/

Edutopia. https://www.edutopia.org/article/can-robot-help-autistic-children-connect 